\title{
The Federal Government and Canadian Universities: A Review
}

\author{
N.L. Nicholson*
}

The Government of Canada began to participate in post-secondary education seven years after Confederation and it has been doing so ever since. Broadly speaking, its involvement has been in three areas - the institutions of higher education; manpower training and retraining programs; and research.

\section{The Nature of the Involvement before 1940}

Involvement with institutions of higher education began with the "Act respecting Queen's College at Kingston" passed by the federal parliament in 1874. Queen's College had, of course, been originally chartered by the legislature of Upper Canada in 1841. But the formation of the Presbyterian Church in Canada, which concerned several provinces, had to be effected through federal legislation. This in turn necessitated amendments to the original charter of Queen's. Consequently, the constitution of Queen's was revised first by the provincial legislature and later confirmed by the federal act. 1

Such involvement continued with the establishment of the Royal Military College in Kingston which was chartered in 1876 by the parliament of Canada under the authority of Section 91 of the British North America Act which enables it to legislate exclusively on matters of "Militia, Military and Naval Service, and Defence." 2

Then in 1883 the parliament of Canada passed "An Act to incorporate the University of Saskatchewan and to authorize the establishment of Colleges within the limits of the Diocese of Saskatchewan". ${ }^{3}$ Embodied in that Act was the requirement that the Senate of the University, "whenever called upon by the Governor General in Council so to do" ... "furnish full and accurate accounts, in writing, of the property of the University, and the income; and also to report fully, in writing, upon any other matters in connection therewith, that the said Governor General in Council may require." The

* N.L. Nicholson, Professor, Altbouse College of Education, University of Western Ontario. 
Province of Saskatchewan had not yet been created in 1883 but, according to Thompson, "although education was not a federal responsibility under the terms of the B.N.A. Act, the M.P.'s no doubt found justification for the federal action in the fact that the territories were not provinces to which the responsibility had been assigned under the act. The legislature of the territories, however, had at least as much right as the federal parliament to issue such a charter" " but there was no territorial legislature in 1883.

Manitoba, however, had been created a province in 1870 and seven years later its legislative assembly had established the University of Manitoba. Nevertheless, in 1885, the federal government enacted that "an allotment of land, not exceeding one hundred and fifty thousands acres, of fair average quality, shall be selected by the Dominion Government and granted as an endowment to the University of Manitoba for its maintenance as a University capable of giving proper training in the higher branches of education, and to be held in trust for that purpose upon some basis or scheme to be framed by the University and approved by the Dominion Government." 5 It is to be noted that there is no formal provision for the involvement of the provincial government in these activities. On the other hand, it is also of note that the clause relating to the University of Manitoba is only one of several which cover diverse matters in "An Act for the final settlement of the claims made by the Province of Manitoba on the Dominion."

A second kind of involvement came about as a result of the Agricultural Aid Act of 1912 and the Agricultural Instruction Act of 1913. ${ }^{6}$ Both the Parliament of Canada and the legislatures of the provinces have jurisdiction over agriculture according to Section 95 of the B.N.A. Act and hence the federal justification for these acts was the exodus of young people from the farms to the cities, which was viewed by the government as a serious national problem. It was believed that the outflow could be averted by increasing educational opportunity, and hence stability and prosperity would be restored to the agricultural industry. "The funds were to be channelled through established constitutional lines using and strengthening the machinery already in existence in the provinces or machinery which would be established by the provinces. ${ }^{8}$

Some special programmes were financed separately. For example, veterinary colleges which awarded degrees were each granted $\$ 20,000$ per year on the grounds that the federal government was involved in veterinary work and the students attending the colleges were drawn from all provinces. ${ }^{9}$

However, these federal grants are generally regarded as having been terminal, i.e., not representing a link to programs presently (1972) in operation. The Technical Education Act of 1919 is widely regarded as the beginning of federal contributions to post-secondary education. By this time, World War I was over and the national government was concerned with "promoting industry and the mechanical trades" 10 rather than agriculture, as it had been in 1912. By virtue of its exclusive authority in matters of defence the federal government felt an obligation to its war veterans. Furthermore, 
the Parliament of Canada, under Section 91 of the B.N.A. Act, has responsibility for "The Regulation of Trade and Commerce" and technical training was expected to improve the quality, quantity and distribution of manufactured goods, and to improve the competitive position of Canadian manufactured goods in foreign markets. Indeed, Stager ${ }^{11}$ claims that this was the "primary argument" for "examining and financing of technical education" by the Federal Government. The Technical Education Act was allowed to lapse in 1929 but federal assistance to technical education was renewed in 1937 under "An Act to assist in the alleviation of Unemployment and Agricultural Distress" 12 which provided for the training of unemployed persons aged 18 to 30 years. It was replaced in 1939 by the Youth Training Act "to provide for the Training of Young People to fit them for Gainful Employment". ${ }^{13}$

\section{Research}

A third major area of university activity into which the federal government entered was research. Federal support for research actually antedated World War I but it was probably not more than $\$ 90,000$ per annum in the years immediately preceding the war and was mostly for agriculture and mining. As Macdonald and others have pointed out, "the watershed in the evolution of federal support for university research" :14 came in 1916 with the appointment of an Honorary Advisory Council for Scientific and Industrial Research, later known as the National Research Council (NRC). It was, of course, conceived in wartime and was intended to supplement the war effort and to develop research for industry and the exploitation of natural resources. But early in 1917 , it instituted a system of scholarships to enable first-class science graduates to take additional training to fit them for research work and a system of grants-in-aid for research to competent scientists, in university or other laboratories, to enable them to buy research equipment and hire technical assistance.

Thus within 50 years of its establishment, the federal government had entered areas which have a bearing on almost every phase of university activity - the establishment of institutions of post-secondary education; the construction and maintenance of university buildings ; the support of certain kinds of curricula ; financial aid to university students and encouragement of scientific research. These have created a number of issues which are still current.

\section{The Constitutional Issues}

The acts of the federal government in themselves provide constitutional precedents which presumably can be repeated. The fact that Queen's University has a "federal charter" has been suggested as justification for federal involvement in universities even though Queen's "federal charter" was necessitated by events outside education and in any case was really only enabling legislation confirming provincial action. The federal endowment of land for the University of Manitoba was also used 
as an argument for similar action in the case of the other prairie universities. As is pointed out in Towards 2000, "there is no shortage of precedents for a continuing involvement in the years ahead"... and... "surely no policies for the future can ever be built on a total rejection of the past." 15

But the real constitutional issue stems from the well-known fact that Section 93 of the British North America Act states that "In and for each Province the Legislature may exclusively make Laws in relation to Education." Despite this the parliament of Canada has obviously passed laws related to education and, as a result, the constitutionality of such federal laws has been questioned. It is not our purpose here to advance the legal arguments for or against the federal position. Each side has its advocates. Hurtubise and Rowat 116 appear to favour the abandonment of all precedents for a federal role in higher education and claim that Macdonald et al ${ }^{14}$ favour an over-extension of the federal role. Bissell ${ }^{17}$ argues for a "double system" - provincial and federal. Peitchinis shows a bias toward provincial control but summarizes his position as follows : -

"The examination of all arguments relating to the constitutionality of the federal participation in the financing of post-secondary education leads to the conclusion that the universities have always been, and are, unequivocally included under Section 93 of the B.N.A. Act, but that there are areas related to education... for which direct federal assistance is not unconstitutional." 18

Consequently, while the constitutional question remains a current issue per se, it is useful to consider the addition issues raised by the purposes, or intent, of the federal government in becoming involved in university education; the means used to accomplish the purposes and the effects or results of the actions of the federal government.

The constitutionality of the federal government in establishing the Royal Military College has never been challenged as its purpose was to train cadets for entry into the commissioned ranks of the armed forces. At the time there was no suggestion that the curriculum would be comparable in substance to that of the universities, but since then R.M.C. has been authorized by the legislature of Ontario to grant degrees and in this respect is like any other university. However, the college is maintained and administered by the Department of National Defence. The Minister of National Defence is ex officio president of the college and its faculty are recruited within the framework of the federal Civil Service Commission. Consequently it can, in some ways, be regarded as an arm of the Civil Service. Yet its courses and graduates are recognized by the more orthodox universities. This being so, the question is whether other "arms of the Civil Service", whose function might be considered to be largely academic, should have the same privileges, especially the right to grant degrees. This issue has been informally discussed from time to time in connection with the National Research Council and some other federal research institutes. 
But broader issues are involved in the actions of the federal government between 1912 and 1940 outlined below. Underlying each of these actions was the fact that the federal government was confronted with a national problem : be it undesirable internal migration ; lack of skilled manpower for industry ; responsibility to its ex-service men or widespread unemployment. It responded by formulating a policy designed to resolve the problem. But as each policy was related to an activity under exclusive provincial jurisdiction, the federal government had to devise various formulae to implement its policies.

In the case of most of the Agricultural Instruction Act, it approached the provinces with a proposal and funds for its implementation which were generally allocated amongst the provinces on a population basis. This appears to be the beginning of federal participation in the financing of education by channelling the funds through the provincial governments. A second device was to make direct grants to certain institutions, as was the case with the veterinary colleges, on the grounds that, as there were only three such institutions at the time, inter-provincial mobility was necessary for those students in whose provinces the programs were not offered. The funds were distributed among the colleges on the basis of student enrolment in each college - the first instances of the concept of "per capita grants". A third device was to make loans and grants to the students themselves. This was used for the first time under the Youth Training Act.

Certain conclusions may be drawn from the pre-1940 period of federal involvement in university affairs. It is clear that such involvement was based on constitutional responsibilities of the federal government which could in part be exercised through the educational systems of the provinces. But the federal government went about achieving the purposes of its various operational departments whether this involved intrusion into provincial domains or not. Consequently, it did not establish any administrative or research machinery to deal rationally with matters of education. Many of its decisions, in so far as they affected education, were ad hoc decisions, the full implications of which were not always appreciated.

Frequently some special device or terminology was used primarily to circumvent a possible collision with the B.N.A. Act. But a number of these administrative arrangements did indicate a way of dealing with particular sets of problems and these basic devices have merely been developed or extended as the involvement of the federal government continued into a latter period.

\section{Post-1940}

It was World War II that set the stage for continued federal involvement in higher education. The nature and magnitude of the war, quite apart from the constitutional responsibility of the federal government for defence, demanded strongly centralized policies. The provinces vacated the personal income and corporate tax fields and the several federal government vocational training programs in existence were consoli- 
dated into the Vocational Training Coordination Act of $1942 .{ }^{19}$ Under this act a number of agreements were made with the provinces which were designed to assist and accelerate the output of personnel, such as doctors and dentists, for war service. But the most direct and extensive federal involvement in the financing of post-secondary education, and of individuals pursuing studies in post-secondary institutions, took place in relation to the financing of World War II veterans. Under the Veterans Rehabilitation Act ${ }^{20}$ (the full title of which was "An Act to provide Rehabilitation Allowances for Veterans") "veterans enrolled in university were eligible for grants covering tuition and a living allowance. In addition the federal government paid a flat sum ( $\$ 150$ per year) to the institution for each veteran enrolled, as a subsidy for the additional staff and facilities made necessary by the influx of veterans. These subsidies continued to be a significant part of university income until the end of 1951 when the bulk of the veterans had completed their university training." 21

But it seems never to have occurred to the universities that when the number of veterans able and willing to pursue higher education diminished so would the income from tuition fees and the federal subsidy. Presumably they expected that federal aid might continue, although the Rowell-Sirois Commission in 1940 had only given cautious approval to it and then only for certain phases of education. ${ }^{22}$ Consequently, with the termination of this support, the universities faced a financial crisis which, in 1951, the Massey Commission described as being "so grave as to threaten their future usefulness." ${ }^{23}$ Acting on the recommendations of this Commission, the government of Canada introduced a system of grants to universities amounting to 50 cents per capita of the population of each province and distributed between the universities in proportion to enrolment. It was designed "primarily to assist the universities to maintain the highly qualified staff and the working conditions which are essential for the proper performance of their functions" ${ }^{24}$ - in other words to maintain the standards achieved through the accommodation to the veteran's programs rather than to increase facilities. The per capita grants were raised to $\$ 1.00$ in 1957 , to $\$ 1.50$ in 1958 , to $\$ 2.00$ in 1962 and to the equivalent of $\$ 5.00$ in 1966 . The provincial governments were not intimately consulted in the distribution of these funds, in part perhaps because they could be considered to be a continuation of the way in which financial aid had been given under the Veterans Rehabilitation Act and to which no provincial government had objected.

However, in 1952, the Prime Minister of Quebec instructed the universities in that Province to refuse the grants as constituting, in his opinion, a trespass on the constitutional rights of the Province. But in 1959 the federal government finally agreed to increase its corporate income tax abatement for Quebec and to pay the province any difference between this and the value of university grants that would otherwise be payable. Then in 1966 this principle was extended to the other provinces when the federal government cancelled its general payments to universities, and phased out its support of technical and vocational training at the secondary level, except for adult occupational training. At the same time it returned part of the taxing powers which the 
provinces had surrendered to it in World War II and agreed to supplement this additional income in order for each province to reach 50 per cent of operating costs of all its post-secondary institutions or (because of regional economic disparity) to equal $\$ 15$ per capita of provincial population, whichever was the larger.

The principal impact of these new arrangements was two-fold. From the point of view of the universities, it meant that all of their general state support now came from one source - the provincial government. As Hanly has expressed it, "after 1966, the dependency of the universities upon provincial government became so predominant as to be absolute." ${ }^{25}$ From the provincial government's point of view, it could now plan and budget for the development of secondary and higher education as a coordinated system.

But these arrangements did not, by any means, resolve all the issues of federal involvement. While overt direct intervention ceased, indirect intervention remains. Two aspects of this are particularly significant - the shared-cost nature of the scheme and the question of university research. "For most provinces the new arrangement is essentially a shared-cost scheme, since each additional dollar spent by the provincial government within the prescribed limits is matched by a federal dollar" and "suffers from the disadvantages characteristic of any cost-sharing plan for a limited purpose." 26 The various implications of this are dealt with thoroughly by Hurtubise and Rowat but three of their main points are as follows: Firstly, the federal government defined the limits of the costs to be shared. Secondly, the scheme presents the problems of defining "inclusions and exclusions" and applying such definitions to the ten different sets of circumstances existing in each of the provinces. Thirdly, the federal government must have evidence of the amounts actually spent on items falling within the definitions, Sheffield is quoted by Hurtubise and Rowat as having said that "the insertion of the shared-cost feature of the arrangement launched the federal government into a process of categorizing and scrutinizing expenditures which made a mockery of the theory of enabling the provinces to assume their constitutional responsibilities in the field of postsecondary education." 27

\section{Research}

The all important question of research was not directly affected by the 1966 arrangements but since 1916, the involvement of the federal government in university research had increased enormously and especially after 1960. The support now comes from two main sources - "The Councils" and the federal departments of government. The Councils are three in number, viz. the National Research Council, the Canada Council created in 1957 (to be a sponsor not only of the humanities and the social sciences but also of the fine and performing arts) and the Medical Research Council, a virtually autonomous creature of the N.R.C., created in the 1960's. Generally the programmes of these councils are regarded as research supporting whereas the programmes of the federal departments of government are regarded as mission-oriented. Macdonald 
traced no fewer than 41 such departments and federal agencies supporting universities research in one way or another in $1969 .{ }^{28}$

The impact of thrusts of such variety and magnitude seems to have had distorting effects upon university research and the development of universities generally. Some of these are the favouring of basic research as opposed to applied research; the bias towards science and engineering as opposed to social science and humanities; the possbile imbalance in the support given to established scholars versus young ones; the overdevelopment of research at the expense of undergraduate work and teaching and the tendency to channel research funds in ever increasing amounts to a few large universities. These effects are encompassed in the broad problem of priorities in the allocation of funds among the various sectors, fields and kinds of research and the issue of the most desirable balance among the different kinds and fields of research. As Hurtubise and Rowat put it, "How much research should be done by government itself, how much by industry and how much by the universities? What is the proper division among the broad fields of knowledge: the natural and biological sciences, the social science and humanities? or between basic and broadly oriented research on the one hand, and applied research on the other?" 29

Much of the federal support has been granted on an uncoordinated basis by many different agencies and without any over-all policy or plan. It has also been granted frequently without regard for provincial interest. Consequently, it is clear that some formal mechanisms are needed to ensure that such complex relationships are handled in an orderly fashion and that the many varied interests are reconciled.

Not the least of these questions involves the individual universities themselves. Many, if not most, universities have been unable to agree on a statement of their purpose and role and the lack of overall goals and objectives has made the setting of priorities and the ordering and management of a vast complex of interrelated detail at an individual university very difficult. Until very recently the same thing could have been said of the provincial governments, but official reports on education which have appeared in the last decade provide statements about the purposes of university education in most provinces. The production of clear aims on the part of the university and the provincial government will reduce uncertainties in both spheres and facilitate the matter of overall federal goals and policies and the position of the existing Councils and Departments.

Macdonald et al. have argued for somewhat reorganized Councils so as to encompass all disciplines recognized by Canadian universities with in Intercouncil Coordinating Committee and a Canadian Universities Research Advisory Committee to make available to Treasury Board advice on the allocation of public funds for sponsored research in Canadian universities. ${ }^{30}$ They also recommend that each mission-oriented agency engaged in research support establish one or more advisory committees made up in part of university representatives, and that one agency be responsible for the development and maintenance of a central register of all research projects and programs funded from 
federal sources. The National Research Council has now established an Information Exchange Centre "to accumulate and make available... information on all federallysupported university research whether this support be by grants, contracts, research agreements, or scholarships... on federal support for university research in the humanities and social sciences as well as in the physical and health sciences..." ${ }^{31}$. The Science Council of Canada suggested that liaison between the granting councils and other federal agencies supporting research be provided by establishing a formal link between the Intercouncil Coordinating Committee and the Advisory Panel on Science and Technology of the federal government. ${ }^{32}$

Figure 1.

SUGGESTED MECHANISMS FOR THE COORDINATION OF FEDERAL GOVERNMENT RESEARCH SUPPORT TO CANADIAN UNIVERSITIES

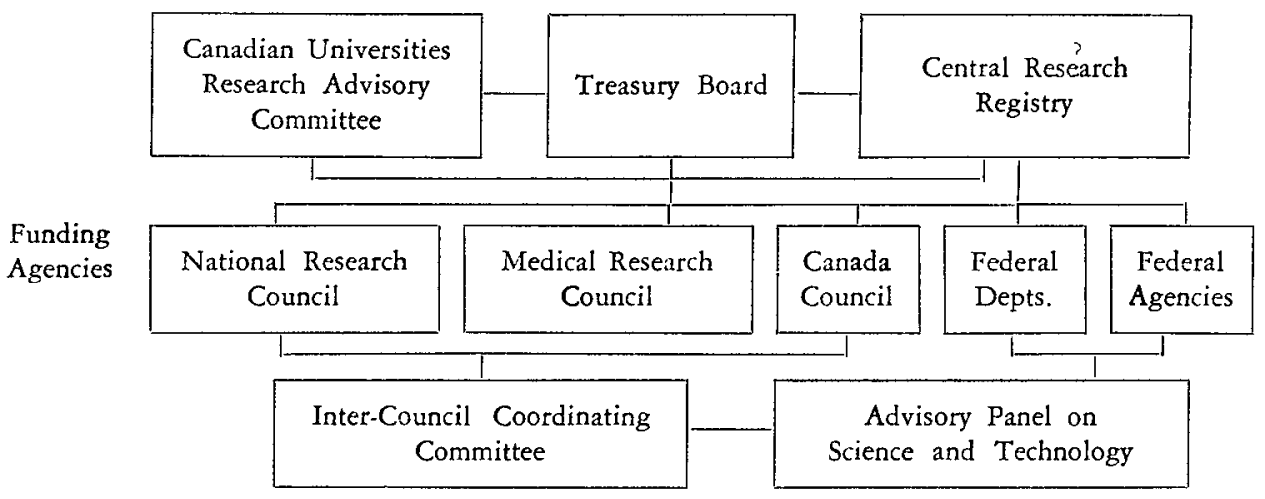

\section{Future federal involvement}

Other ways in which a greater federal involvement in higher education might occur have also been put forward. A report prepared for the Committee of Presidents of Universities of Ontario ${ }^{33}$ makes several such suggestions. It includes the establishment of professional chairs by the federal government; the establishment of a certain number of national institutions of higher learning or the take-over of certain existing ones and the assumption of responsibility for all post-graduate and post-first degree professional education in Canada, including student support. Graduate work has two special features (i) it is expensive and (ii) it is "in and for the nation and the world" rather than "in and for each province". ${ }^{34}$ The Canadian Deans of Graduate Studies, in 1964, stated that "graduate studies and research fall more directly into the realm of federal responsibility than do the less costly lower levels of education". ${ }^{35}$ Bissell recognizes this as "the most plausible" role for the federal government and maintains that such an argument for federal involvement is educational (i.e., not financial and not political). "A federal in- 
terest will mean a more bracing atmosphere, less constricted and introverted, more receptive to international ideas and needs. Moreover, the national interest will be quicker to make qualitative judgments, to support strength, and will be more reluctant to sustain mediocrity." 36

If this position is accepted, it is then possible to devise a model for the interaction of the sources of funds. Forward has produced a possible model ${ }^{37}$ (Figure 2) despite the fact that it was intended for science education and is incomplete in that it does not provide for the needs of the immediate community (assuming that a given university feels that it must serve such needs).

Figure 2.

THE "FORW ARD MODEL"

\begin{tabular}{|l|l|r|r|}
\hline $\begin{array}{l}\text { Source of funds } \\
\text { Provincial Governments }\end{array}$ & Federal Government & $\begin{array}{c}\text { Industry and } \\
\text { Government Agencies }\end{array}$ \\
Participants & $\begin{array}{c}\text { Faculty } \\
\text { Undergraduate }\end{array}$ & $\begin{array}{c}\text { Faculty } \\
\text { Graduates } \\
\text { Post-doctoral Fellows }\end{array}$ & $\begin{array}{r}\text { Faculty (part-time) } \\
\text { Professional Train??? } \\
\text { Technicians }\end{array}$ \\
Content & Background Knowledge & Frontier of Science & Applied Research \\
\hline
\end{tabular}

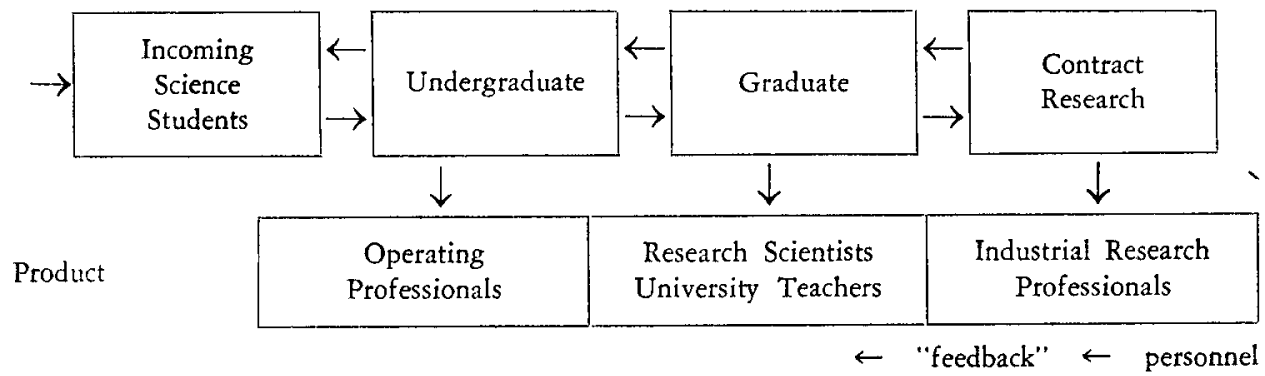

However, this approach still leaves the questions unanswered of the amount and kind of research and where precisely it should be conducted, and in 1971 the Association of Universities and Colleges of Canada commissioned an investigation of the rationaliza- 
tion of university research. The commission clearly recognized the need for the universities to "set" their research houses "in order" ; it also recognized the validity of some of the suggestions in Towards 2000, which were mentioned earlier and it eschews discussion of the constitutional issue of federal involvement and links research with "international stature" (Recommendation 13) and the "pursuit of high national purpose" (Recommendation 14). Its principle recommendations, insofar as the federal government is concerned, are as follows :-

"... that the federal agencies make payments to the universities designed to cover the indirect costs of the research they sponsor, including salaries, that failing a federalprovincial agreement on an alternative figure, these be set at $45 \%$ of the amount of each grant, and paid as general revenues of the universities.

... there will have to be special attention on a national basis by the federal government to selecting across the country centres of specialisation, recognising, and helping to build up in them, first class research competence in a limited number of departments and/or faculties:

... an effort by the Government of Canada... to select experimentally seven to nine graduate schools across the country that have shown really good quality in graduate work in at least two of the main social sciences disciplines.

... that federal councils consider setting aside a small percentage of their funds to be used as risk capital in the freld of research." 38

There the matter rests while the debate on these aspects of federal involvement continues. In concluding, it is worth noting that these embrace all those phases of university activity into which the federal government had entered by 1917. But it is not quite a matter of the wheel having come full circle. This time the proposals are within an overall framework and strategy.

\section{Acknowledgments}

The author is indebted to Dr. John B. Macdonald and Dr. Edward F. Sheffield, Professors of Higher Education at the University of Toronto, for reviewing the manuscript and making many valuable suggestions.

\section{References}

1. Staiutes of Canada, 38 Vict., 1874, Ch. LXXVI.

2. Statutes of the United Kingdom, 30-31 Vict., 1867, Ch. 3 .

3. Statutes of Canada, 46 Vict., 1883, Ch. 47. It should be noted that this University of Saskatchewan is not the present day institution of the same name.

4. Thompson, W.P. The University of Saskatchewain. A Personal History. Toronto, University of Toronto Press, 1970, p. 5.

5. Statutes of Canada, 48-49 Vict., 1885, Ch. 50.

6. Statutes of Canada, 2 Geo. V, 1912, Ch. 3 and 3.4 Geo. V, 1913, Ch. S.

7. Fluxgold, Howard. Federal Financial Support for Secondary Education and its effect on Ontario 1900-1972, Toronto, Ontario Teachers' Federation, 1972. 
8. Debates, House of Commons of Canada, 1912-13, p. 2152.

9. Maxwell, J.A. Federal subsidies to the Provincial Governments in Canada. Cambridge, Mass., Harvard University Press, 1937, p. 200.

10. Statutes of Canada, 9-10 Geo. V, 1919, Ch. 73.

11. Stager, David A.A. The evolution of Federal Government Financing of Canadian Universities, Stoa, II, 1972, P. 24.

12. Statutes of Canada, 1 Geo. VI, 1937, Ch. 44.

13. Statutes of Canada, 3 Geo. VI, 1939, Ch. 35.

14. Macdonald, John B. et al, The Role of the Federal Government in support of research in Cunadian Universities, Ottawa, Queen's Ptinter, 1969, p. 63.

15. Porter John, Bernard Blishen et al., Tonturds 2000, Toronto, McClelland and Stewart, 1971, p. 127.

16. Hurtubise, R. and Donald C. Rowat. The University, Society and Government, Ottawa, Ottawa University Press, 1970, p. 133 and 179-180.

17. Bissell, Claude T. "Canada" in Higher Educaiion: From Autonomy to Systems, ed. by James A. Perkins, New York, International Council for Educational Development, 1972, p. 183.

18. Peitchinis, Stephen G. Financing Post Secondary Education in Canada, Council of Ministers of Education of Canada, 1971, p. 33.

19. Statutes of Canada, 6 Geo. VI, 1942, Ch. 34 .

20. Statutes of Canada, 9-10 Geo. VI, 1945, Ch. 35.

21. Hanly, Charles. Wbo Pays? University Financing in Ontario, Totonto, James Lewis and Samuel, 1970 , p. 12.

22. Repont of the Royal Commission on Dominion-Provincial Relations, II, Ottawa, King's Printer, 1940, p. 50.

23. Report of the Royal Commission on National Development in the Arts, Letters and Sciences, Ottawa, King's Printer, 1951.

24. Debates, House of Commons of Canada, 1951, p. 4278.

25. Hanly, op cit., p. 16.

26. Hurtubise and Rowat, op. cit., p. 142.

27. Ibid., p. 143.

28. Macdonald, et al., op. cit., p. 64.

29. Hurtubise and Rowat, op. cit., p. 159.

30. Macdonald, et al., op. cit., p. xx.

31. Report of the President 1970-71, Ottawa, National Research Council, 1971.

32. University Research and the Federal Government, Ottawa, Queen's Printer, 1969, p. 28.

33. Porter, Blishen et al., op. cit., pp. 133-137.

34. Ibid., p. 135 .

35. Bladen, V.W. et al., Financing Higber Education in Canada, Toronto, University of Toronto Press, 1965, p. 51.

36. Bissell, loc. cit.

37. Forward, F.A. "The Role of Governments in Science Education" in Higher Education in a Changing Canada, ed. by J.E. Hodgetts, Toronto, University of Toronto Press, 1966, p. 79.

38. Bonneau, Louis Philippe and Corry, J.A. Quest for the Optimum: Research Policies in the Universities of Canada, Ottawa, Association of Universities and Colleges of Canada, 1972. 